\title{
Analisa Faktor Pelayanan Bandara Juanda dengan Menggunakan Metode Structural Equation Modelling
}

\author{
Rizfanni Cahya Putri ${ }^{(1)}$, Uranio Bimo ${ }^{(2)}$ \\ Sekolah Tinggi Ilmu Ekonomi Indonesia (STIESIA) Surabaya ${ }^{(1)}$ \\ Institut Teknologi Sepuluh Nopember (ITS) ${ }^{(2)}$ \\ Jl. Menur Pumpungan No.30, Kec. Sukolilo, Kota SBY, Jawa Timur $60118^{(1)}$ \\ Jl. Cokroaminoto No.12A, DR. Soetomo, Kec. Tegalsari, Kota SBY, Jawa Timur $60264^{(2)}$ \\ e-mail: rizfannicahyaputri@stiesia.ac.id dan uraniobimo03@gmail.com
}

\begin{abstract}
ABSTRAK
Bandar Udara Juanda merupakan salah satu dari sarana/fasilitas pemenuh kebutuhan transportasi udara yang dikelola oleh PT. Angkasa Pura I, sesuai dengan peraturan Menteri Perhubungan RI no. 38 tahun 2015 dimana pengelolaan Bandar udara harus berkualitas dari sarana dan pelayanan terhadap pengguna jasa, maka pengelola dituntut untuk memberikan pelayanan secara maksimal. Pada tahun 2017, kapasitas daya tampung penumpang di Bandar Udara Juanda terminal 1 sudah mengalami overload sekitar 17 juta penumpang per tahun dari kapasitas desain pembangunan 2006 hanya 6 juta per tahun, dengan demikian dapat diprediksi akan timbul penurunan kepuasan pengguna jasa akibat dari penurunan level of service dari pelayanan yang secara kapasitas desain. Pada awal tahun 2018 dilakukan perubahan fasilitas dan pelayanan dari pengelola. Setelah dilakukan penelitian dengan metode SEM-PLS menginformasikan bahwa kualitas pelayanan tidak sepenuhnya berpengaruh terhadap kepuasan dan loyalitas pengguna jasa, namun kepuasan pengguna jasa berpengaruh terhadap loyalitas pengguna jasa.
\end{abstract}

Kata kunci : Kualitas Pelayanan, Kepuasan Pengguna Jasa, Loyalitas Pengguna Jasa, Structural Equation Modelling (SEM).

\section{ABSTRACT}

Juanda International Airport as a facility for air transportation managed by PT. Angkasa Pura I. According to the Regulation of Transportation Ministry of Indonesian Republic no. 38/2015, the airport management must meet the quality standard to provide the customers (airplane passenger) both facilities and services. Thus, the management has to provide their maximum service. On 2017, the capacity of passenger is overloaded in Terminal I of Juanda International Airport for 17 million passengers recorded per year. Whereas, regarding to the design capacity development at 2006, there are 6 million passengers per year. Hence, the decreasing of customer's satisfactory might happen due to lower service level. However, on early 2018, there was an upgrade in facilities and services done by the management. The research conducted by the SEM-PLS method determined that service quality does not significantly affect customer satisfaction and loyalty. However, the customer satisfaction directly affects the customer loyalty.

Keywords : Service Performance, Customer Satisfation, Customer Loyalty, Structural Equation Modelling (SEM).

\section{PENDAHULUAN}

Pengelolaan transportasi udara khususnya Bandar udara, pihak pengelola mendapatkan fee dari pengguna jasa seperti tiket parkir, airport tax, harga sewa lahan tenant / toko penjualan, iklan dan lainnya. Dengan demikian dikarenakan ada biaya yang harus dikeluarkan pengguna jasa perihal penggunaan layanan di Bandar udara maka akan memunculkan persepsi terhadap layanan suatu produk ataupun jasa.
Selain itu dari adanya kepuasan maka dimungkinkan pengguna jasa akan memunculkan suatu loyalitas (Cronin, 1992), serta Tjiptono (1997) menjelaskan bahwa terciptanya kepuasan pelanggan dapat memberikan beberapa manfaat yaitu terjadinya hubungan harmonis antara perusahaan dan pengguna jasa, memberikan pembelian ulang produk atau jasa yang ditawarkan suatu perusahaan terhadap konsumen serta dapat menimbulkan loyalitas dari pengguna jasa. 
Loyalitas pengguna jasa memiliki arti penting dalam sebuah perusahaan dalam memajukan bisnis yang dikerjakan dan kelangsungan hidup perusahaan. Selain itu umumnya loyalitas berasal dari tindak lanjut yang diberikan pengguna jasa perihal kepuasan terhadap layanan yang diberikan oleh suatu perusahaan (Lovelock, 2011). Loyalitas didefinisikan sebagai perasaan senang atau kecewa pengguna jasa yang muncul akibat membandingkan persepsi atau kesan terhadap kinerja suatu layanan / produk dengan ekspektasi yang diharapkan (Kotler, 2001).

Jika suatu perusahaan jasa pengelola transportasi mengalami penurunan kepuasan dan tidak diberikan tindakan yang serius maka dapat dimungkinkan pengguna jasa akan beralih jenis tranportasi jalur lainnya seperti jalur darat maupun air, mengingat sekarang fasilitas transportasi mulai diperbarui dan membuat nyaman pengguna jasanya. Sejalan dengan itu Kasmir (2005) memberikan pendapat bahwa setiap perusahaan yang memberikan pelayanan di sektor transportasi umum harus memperhatikan tingkat kepuasan pengguna jasa di area bisnisnya, agar bisnis tersebut tetap dapat bertahan.

Cara menilai hal tersebut terdapat beberapa dimensi yang dapat digunakan dalam menilai tingkat kepuasan pengguna jasa terhadap pelayanan yang diberikan serta tingkat loyalitas pengguna jasa. Terdapat lima dimensi yang dapat mempermudah pengukuran kepuasan pengguna jasa, yaitu responsiveness, reliability, assurance, emphaty dan tangibles (Zeithaml, 2011). Serta loyalitas pengguna jasa dapat diukur dengan cara seberapa sering membeli suatu produk secara berulang, merefrensikan kepada orang lain, tetap setia dengan suatu produk (Griffin, 2005).

\section{METODE PENELITIAN}

a. Studi Literatur

Dalam tahap ini dilakukan studi dengan cara membaca berbagai kumpulan literature seperti buku, thesis, ataupun tugas akhir tentang kepuasan pengguna jasa teruatama yang membahas permasalahan di Bandar Udara. Sehingga mendapatkan ide terkait survei maupun metode yang dapat digunakan untuk menyelesaikan masalah.

b. Pembuatan Kuisioner Survei

Setelah topik didapatkan tentang kepuasan pelanggan Bandar Udara Juanda, maka mulai dipilih aspek ataupun faktor yang menjadi penilaian terkait infrastruktur maupun pelayanan yang diberikan oleh pihak pengelola terhadap pengguna jasa. Selain itu juga harus mempertimbangkan responsiveness, reliability, assurance, emphaty, tangibles, satisfaction, dan loyalty dalam pemilihan atribut pertanyaan yang akan digunakan. Serta menentukan jumlah sampel yang akan dilakukan survei kuisioner, seperti berikut:

Bentuk Fisik (Tangibles)

1) Penampilan staff bandar udara rapi, bersih, dan sopan (X1).

2) Keadaan fasilitas di bandar udara baik, nyaman, dan bersih (X2).

3) Bentuk fisik bangunan, pentaan ruangan, ruang tunggu serta jumlah tenant membuat nyaman dan terpenuhi (X3).

\section{Keandalan (Reliability)}

1) Pelayanan xray scan berjalan dengan cepat dan tepat (X4).

2) Pelayanan check in bagasi dan boarding pass cepat dan tepat (X5).

3) Pelayanan check in -2 menuju ruang tunggu cepat dan tepat (X6).

4) Kejelasan dan ketepat dalam pemberian informasi (X7).

5) Pelayanan sesuai prosedur yang ada (X8).

6) Airport tax / biasa sewa tenant sesuai dengan kualitas pelayanan (X9).

\section{Daya Tanggap (Responsiveness)}

1) Fleksibilitas staff bandar udara saat bantuan diperlukan (X10).

2) Ketersediaan tempat layanan keluhan (X11).

3) Staff bandar udara cepat dan tepat menyelesaikan masalah (X12).

Jaminan (Assurance)

1) Staff bandar udara bersikap adil dan memberikan keamanan bagi pengguna jasa saat mendapatkan pelayanan dan beraktifitas (X13).

2) Keamanan saat melakukan aktifitas di bandar udara (X14).

Empati (Empathy)

1) Ketersediaan fasilitas untuk difabel (X15).

2) Permohonan maaf dari staff jika ada kesalahan dalam pelayanan (X16).

Kepuasan (Satisfaction)

1) Pengguna jasa merasakan senang dan nyaman saat menggunakan pelayanan (Y1).

2) Keteraturan pelayanan yang baik (Y2).

3) Pengguna jasa tidak mempermasalahkan harga untuk mendapatkan pelayanan yang lebih (Y3).

4) Pengguna jasa tidak pernah komplain terhadap pelayanan/produk yang diberikan (Y4).

\section{Loyalitas (Loyalty)}

1) Memberikan informasi positif tentang pelayanan ke pihak lain $(\mathrm{Z} 1)$.

2) Tetap setia dengan produl/layanan meskipun ada penawaran dari pihak pesaing (Z2). 
3) Menggunakan jasa/produk secara berulang dalam waktu tertentu (Z3).

4) Memberikan perhatian ataupun saran secara berkala terhadap suatu pelayanan/produk yang ada (Z4).

c. Survei Lapangan

Survei yang dilakukan langsung dengan mewawancari pengguna jasa di Bandar Udara Juanda, maupun dapat menggunakan kuisioner yang diberikan secara acak kepada beberapa orang yang pernah menggunakan pelayanan penerbangan di Bandar Udara Juanda Surabaya selama tahun 2018.

d. Analisa Data Hasil Survei

Dari data survei yang didapatkan, maka akan dilakukan perhitungan lebih lanjut dengan metode tertentu yang akan digunakan serta melakukan deskripsi sementara terkait hasil survei.

e. Uji Validitas dan Reliabilitas

Melakukan uji validitas dan reliabilitas untuk membandingkan apakah data yang didapatkan dengan jumlah atribut serta sampel tertentu dapat dikatakan valid atau tidak. Jika valid maka dapat dilakukan tahap selanjutnya. Sedangkan reliabilitas dengan pengertian apakah atribut yang digunakan dalam survey ini dapat digunakan dalam konteks yang sejenis. Jika hasil perhitungan validitas dan reabilitas dinyatakan tidak valid maupun reliabilitas maka harus diadakan perubahan kuisioner terhadap atribut yang dihitung.

f. SEM (Structural Equation Modelling)

Persamaan yang digunakan dikarenakan adanya 3 variabel dalam sebuah proses penelitian, lalu menggunakan metode Partial Least Square (PLS) dimana bertujuan memprediksi hubungan antara variabel pelayanan, kepuasan pengguna jasa, serta loyalitas pengguna jasa. Secara umum pengerjaan penelitian ini sebagai berikut untuk metode SEM dengan alat bantu smartPLS:

1) Pengelolahan data dari kuisioner menjadi tampilan program smartPLS dengan memastikan bahwa semua hasil kuisioner yang akan dimasukkan tidak ada nilai kosong pada atribut pernyataannya. Jika ada data yang kosong maka lebih baik hasil kuisioner dari responden tersebut diganti dengan responden lain.

2) Pembuatan path diagram dengan memasukkan setiap manifest pada variabel laten eksogen dan endogen tertentu.

3) Analisa outer model yang bertujuan memberikan informasi terkait validitas dan reliabel. Bertujuan mendefinisikan setiap atribut dengan variabel latennya bersifat reflektif.

4) Dengan beberapa indikator reflektif adalah:

- Loading factor $>0.6$
- Composite reliability > 0.6

- Average variance extracted (AVE) > 0.5

\section{HASIL DAN PEMBAHASAN}

A. Uji Validitas

Setelah mendapatkan data primer dari hasil penyebaran kuisoner yang terdiri dari 24 atribut/variabel, maka harus dilakukan uji validitas untuk mengetahui apakah atribut/variabel yang digunakan sudah cocok digunakan kepada pengguna jasa atau dapat dikatan valid, menggunakan metode pearson dengan bantuan Microsoft excel. Nilai yang dihasilkan dari metode pearson $\mathrm{r}$ harus lebih besar dari nilai $\mathrm{r}$ (koefisien korelasi) dalam tabel $\mathrm{r}$ agar dapat dikatakan valid, jika tidak maka dinyatakan valid dan variabel/atribut tersebut harus dihapuskan untuk melakukan analisa lebih lanjut. Nilai $r$ pada tabel untuk jumlah sampel sebanyak 130 orang adalah 0.1723

Tabel 1. Tabel Validitas

\begin{tabular}{cccc}
\hline Variabel & $\begin{array}{c}\text { Nilai } \\
\text { Pearson }\end{array}$ & $\begin{array}{c}(\mathbf{r}) \\
\text { Tabel }\end{array}$ & Validitas \\
\hline X1 & 0.555 & 0.1723 & Valid \\
X2 & 0.589 & 0.1723 & Valid \\
X3 & 0.577 & 0.1723 & Valid \\
X4 & 0.590 & 0.1723 & Valid \\
X5 & 0.651 & 0.1723 & Valid \\
X6 & 0.673 & 0.1723 & Valid \\
X7 & 0.672 & 0.1723 & Valid \\
X8 & 0.674 & 0.1723 & Valid \\
X9 & 0.592 & 0.1723 & Valid \\
X10 & 0.688 & 0.1723 & Valid \\
X11 & 0.715 & 0.1723 & Valid \\
X12 & 0.782 & 0.1723 & Valid \\
X13 & 0.726 & 0.1723 & Valid \\
X14 & 0.680 & 0.1723 & Valid \\
X15 & 0.757 & 0.1723 & Valid \\
X16 & 0.786 & 0.1723 & Valid \\
Y1 & 0.802 & 0.1723 & Valid \\
Y2 & 0.779 & 0.1723 & Valid \\
Y3 & 0.216 & 0.1723 & Valid \\
Y4 & 0.288 & 0.1723 & Valid \\
Z1 & 0.801 & 0.1723 & Valid \\
Z2 & 0.670 & 0.1723 & Valid \\
Z3 & 0.177 & 0.1723 & Valid \\
Z4 & 0.298 & 0.1723 & Valid \\
\hline D21 Tat & 1 & 01725 & bat
\end{tabular}

Dari Tabel 1 dapat dilihat bahwa semua variabel yang ada dalam kuisioner dinyatakan valid dengan bantuan perhitungan Microsoft excel serta pengecekan lebih lanjut pada software SPSS. Maka semua variabel tersebut mencerminkan dapat diterima atau cocok oleh pengguna jasa yang ada 
serta dapat dilakukan analisa lebih lanjut menuju uji reliabilitas dan lainnya.

\section{B. Uji Reliabilitas}

Untuk menguji reliabilitas akan menggunakan alat bantu berupa software SPSS. Hasil dari reliabilitas ini akan menghasilkan apakah variabel yang dinyatakan valid akan diterima juga dalam hal reliabilitas secara keseluruhan. Batasan nilai berdasarkan cronbach alpha adalah lebih dari 0.7 untuk reliabilitas dikatakan baik.

Tabel 2. Reliabilitas Variabel

\begin{tabular}{c|c}
\hline Cronbach's Alpha & Nof Items \\
\hline 0.932 & 24 \\
\hline
\end{tabular}

Dari Tabel 2 terlihat bahwa nilai reliabilitas dari keseluruhan variabel yang berjumlah 24 pertanyaan bernilai 0.932 , dimana melebihi nilai minimal yaitu 0.7. Dengan demikian maka dapat dikatakan bahwa atribut atau variabel yang digunakan dalam kuisioner ditanyakan reliabel dan pertanyaan pada variabel atau atribut yang ada dapat digunakan untuk penelitian yang sejenis.

\section{Structural Equation Modelling}

Dalam melakukan uji SEM, terlebih dahulu data kuisioner terkait performa aktual hasil survey diolah dengan bantuan smartPLS.Yang bertujuan untuk menggambarkan bentuk path diagram sebagai model structural penelitian yang sedang dilakukan, terkait panduan untuk analisa 3 variabel laten seperti kualitas pelayanan, kepuasan pengguna jasa, loyalitas pengguna jasa.

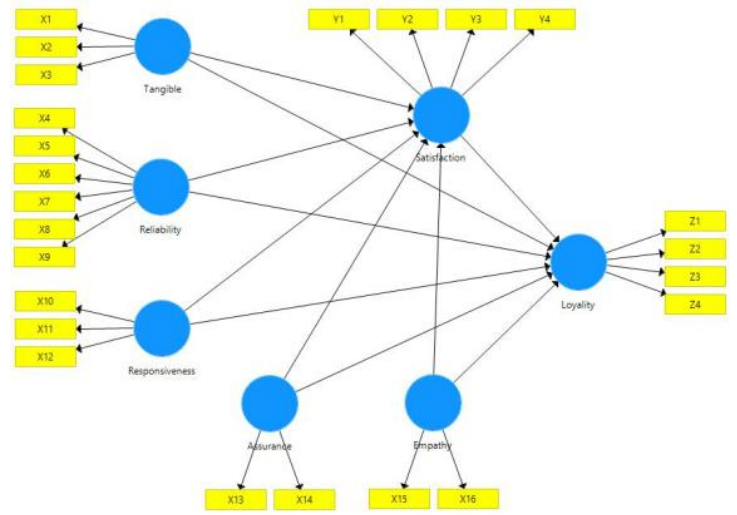

\section{a. Uji Validitas Konvergen}

Setelah dilakukan pembuatan model struktural / path diagram sebagai acuan pengerjaan penelitian, maka harus dilakukan uji validitas konvergen berdasarkan software smartPLS yang digunakan, hasil validitas bertujuan untuk mengetahui hubungan antara indikator penelitian dengan variabel latennya sendiri. Diambil berdasarkan nilai hasil running outer loading, jika outer loading bernilai lebih besar daripada 0.7 maka dikatakan validitas tinggi (Ghozali, 2014), namun menurut Chin (1988) jika outer loading bernilai minimal 0.5 maka dapat dikatakan cukup memadai. Sebuah indikator merupakan reflektif atau salah satu pencerminan suatu variabel latennya sendiri serta memenuhi convergen validity.

Tabel 3. Nilai Outer Loading Running 1

\begin{tabular}{|c|c|c|c|}
\hline Variabel & Indikator & $\begin{array}{c}\text { Outer } \\
\text { Loading }\end{array}$ & Validitas \\
\hline \multirow{3}{*}{ Tangible } & $\mathrm{X} 1$ & 0.671 & Valid \\
\hline & $\mathrm{X} 2$ & 0.892 & Valid \\
\hline & $\mathrm{X} 3$ & 0.850 & Valid \\
\hline \multirow{2}{*}{ Reliability } & $\mathrm{X} 4$ & 0.660 & Valid \\
\hline & $\mathrm{X} 5$ & 0.809 & Valid \\
\hline \multirow{4}{*}{ Reliability } & X6 & 0.833 & Valid \\
\hline & $\mathrm{X} 7$ & 0.784 & Valid \\
\hline & $\mathrm{X} 8$ & 0.813 & Valid \\
\hline & X9 & 0.690 & Valid \\
\hline \multirow{3}{*}{ Responsiveness } & $\mathrm{X} 10$ & 0.790 & Valid \\
\hline & $\mathrm{X} 11$ & 0.845 & Valid \\
\hline & $\mathrm{X} 12$ & 0.892 & Valid \\
\hline \multirow{2}{*}{ Assurance } & $\mathrm{X} 13$ & 0.901 & Valid \\
\hline & X14 & 0.857 & Valid \\
\hline \multirow{2}{*}{ Empathy } & X15 & 0.881 & Valid \\
\hline & X16 & 0.919 & Valid \\
\hline \multirow{4}{*}{ Satisfaction } & Y1 & 0.902 & Valid \\
\hline & $\mathrm{Y} 2$ & 0.890 & Valid \\
\hline & Y3 & 0.313 & $\begin{array}{l}\text { Tidak } \\
\text { Valid }\end{array}$ \\
\hline & Y4 & 0.452 & $\begin{array}{l}\text { Tidak } \\
\text { Valid }\end{array}$ \\
\hline \multirow{4}{*}{ Loyalty } & $\mathrm{Z1}$ & 0.911 & Valid \\
\hline & $\mathrm{Z} 2$ & 0.841 & Valid \\
\hline & $\mathrm{Z} 3$ & 0.306 & $\begin{array}{l}\text { Tidak } \\
\text { Valid }\end{array}$ \\
\hline & $\mathrm{Z} 4$ & 0.289 & $\begin{array}{l}\text { Tidak } \\
\text { Valid }\end{array}$ \\
\hline $\begin{array}{l}\text { Dikarenak } \\
\text { bernilai lebih } \mathrm{r} \\
\text { mempunyai pen } \\
\text { latennya dan ha } \\
\text { lanjut serta dilak }\end{array}$ & $\begin{array}{l}\text { n atribut pen } \\
\text { ndah dari } 0 \\
\text { usuh yang } \mathrm{k} \\
\text { us dihilangk }\end{array}$ & $\begin{array}{l}\text { litian Y3, } \\
5 \text { maka } \\
\text { cil terhad } \\
n \text { untuk an }\end{array}$ & $\begin{array}{l}4, \mathrm{Z3}, \mathrm{Z4} \\
\text { cara teori } \\
\text { variabel } \\
\text { lisa lebih }\end{array}$ \\
\hline
\end{tabular}

Tabel 4. Nilai Outer Loading Running II

\begin{tabular}{cccc}
\hline Variabel & $\begin{array}{c}\text { Indik } \\
\text { ator }\end{array}$ & $\begin{array}{c}\text { Outer } \\
\text { Loading } \\
\text { Setelah } \\
\text { Eliminasi }\end{array}$ & $\begin{array}{c}\text { Outer } \\
\text { Loading } \\
\text { Sebelum } \\
\text { Eliminasi }\end{array}$ \\
\hline Tangible & X1 & 0.666 & 0.671 \\
& X2 & 0.892 & 0.892 \\
Reliability & X3 & 0.853 & 0.850 \\
\hline & X5 & 0.658 & 0.660 \\
& X6 & 0.81 & 0.809 \\
\hline
\end{tabular}




\begin{tabular}{|c|c|c|c|c|c|c|c|}
\hline Variabel & $\begin{array}{l}\text { Indik } \\
\text { ator }\end{array}$ & $\begin{array}{c}\text { Outer } \\
\text { Loading } \\
\text { Setelah } \\
\text { Eliminasi }\end{array}$ & $\begin{array}{c}\text { Outer } \\
\text { Loading } \\
\text { Sebelum } \\
\text { Eliminasi }\end{array}$ & Variabel & $\begin{array}{l}\text { Indik } \\
\text { ator }\end{array}$ & $\begin{array}{c}\text { Outer } \\
\text { Loading } \\
\text { Setelah } \\
\text { Eliminasi }\end{array}$ & $\begin{array}{c}\text { Outer } \\
\text { Loading } \\
\text { Sebelum } \\
\text { Eliminasi }\end{array}$ \\
\hline \multirow{6}{*}{$\begin{array}{c}\text { Responsivene } \\
\text { ss }\end{array}$} & $\mathrm{X} 7$ & 0.784 & 0.784 & \multirow{3}{*}{ Loyalty } & $\mathrm{Y} 2$ & 0.913 & 0.890 \\
\hline & $\mathrm{X} 8$ & 0.815 & 0.813 & & $\mathrm{Z1}$ & 0.923 & 0.911 \\
\hline & X9 & 0.691 & 0.690 & & $\mathrm{Z} 2$ & 0.868 & 0.841 \\
\hline & $\mathrm{X} 10$ & 0.793 & 0.790 & \multicolumn{4}{|c|}{ Dari hasil uji validitas konvergen pada tabel 3} \\
\hline & X11 & 0.841 & 0.845 & \multirow{4}{*}{\multicolumn{4}{|c|}{$\begin{array}{l}\text { serta running ulang pada tabel } 4 \text { maka terlihat } \\
\text { bahwa keseluruhan loading factor dari setiap } \\
\text { atribut mempunyai nilai lebih dari } 0.6 \text { terhadap } \\
\text { variabel latennya. Sehingga atribut penelitian dapat } \\
\text { digunakan untuk pengujian selanjutnya. } \\
\text { b. Uji Validitas Diskriminan }\end{array}$}} \\
\hline & $\mathrm{X} 12$ & 0.893 & 0.892 & & & & \\
\hline \multirow{2}{*}{ Assurance } & X13 & 0.901 & 0.901 & & & & \\
\hline & X14 & 0.857 & 0.857 & & & & \\
\hline \multirow{2}{*}{ Empathy } & X15 & 0.881 & 0.881 & \multirow{3}{*}{\multicolumn{4}{|c|}{$\begin{array}{l}\text { Pengujian validitas diskriminan bertujuan } \\
\text { mengetahui apakah atribut dasar dalam sebuah } \\
\text { variabel latennya mempunyai pengaruh yang lebih } \\
\text { besar dari atribut lain dalam sebuah penelitian. }\end{array}$}} \\
\hline & $\mathrm{X} 16$ & 0.919 & 0.919 & & & & \\
\hline Satisfaction & Y1 & 0.916 & 0.902 & & & & \\
\hline
\end{tabular}

Tabel 5. Nilai Uji Validitas Diskriminan Cross Loading

\begin{tabular}{cccccccc}
\hline Atribut & Tangible & Reliability & Responsive & Assurance & Empathy & Satisfaction & Loyalty \\
\hline X1 & $\mathbf{0 . 6 6 6}$ & 0.486 & 0.451 & 0.446 & 0.391 & 0.380 & 0.322 \\
X2 & $\mathbf{0 . 8 9 3}$ & 0.348 & 0.486 & 0.449 & 0.402 & 0.509 & 0.477 \\
X3 & $\mathbf{0 . 8 5 3}$ & 0.339 & 0.472 & 0.422 & 0.408 & 0.501 & 0.469 \\
X4 & 0.469 & $\mathbf{0 . 6 5 8}$ & 0.486 & 0.414 & 0.462 & 0.345 & 0.319 \\
X5 & 0.354 & $\mathbf{0 . 8 1 0}$ & 0.507 & 0.388 & 0.536 & 0.468 & 0.513 \\
X6 & 0.360 & $\mathbf{0 . 8 3 1}$ & 0.450 & 0.394 & 0.578 & 0.493 & 0.548 \\
X7 & 0.415 & $\mathbf{0 . 7 8 4}$ & 0.516 & 0.504 & 0.505 & 0.481 & 0.545 \\
X8 & 0.334 & $\mathbf{0 . 8 1 5}$ & 0.502 & 0.451 & 0.605 & 0.543 & 0.590 \\
X9 & 0.260 & $\mathbf{0 . 6 9 1}$ & 0.478 & 0.488 & 0.501 & 0.482 & 0.383 \\
X10 & 0.400 & 0.615 & $\mathbf{0 . 7 9 3}$ & 0.564 & 0.558 & 0.537 & 0.479 \\
X11 & 0.509 & 0.419 & $\mathbf{0 . 8 4 1}$ & 0.649 & 0.635 & 0.598 & 0.546 \\
X12 & 0.537 & 0.576 & $\mathbf{0 . 8 9 3}$ & 0.640 & 0.627 & 0.700 & 0.686 \\
X13 & 0.523 & 0.470 & 0.701 & $\mathbf{0 . 9 0 2}$ & 0.591 & 0.638 & 0.555 \\
X14 & 0.412 & 0.538 & 0.579 & $\mathbf{0 . 8 5 6}$ & 0.609 & 0.548 & 0.450 \\
X15 & 0.466 & 0.668 & 0.574 & 0.583 & $\mathbf{0 . 8 8 1}$ & 0.604 & 0.580 \\
X16 & 0.423 & 0.592 & 0.711 & 0.639 & $\mathbf{0 . 9 1 9}$ & 0.737 & 0.686 \\
Y1 & 0.599 & 0.525 & 0.689 & 0.680 & 0.695 & $\mathbf{0 . 9 1 6}$ & 0.742 \\
Y2 & 0.456 & 0.603 & 0.649 & 0.558 & 0.677 & $\mathbf{0 . 9 1 3}$ & 0.782 \\
Z1 & 0.522 & 0.596 & 0.698 & 0.561 & 0.690 & 0.840 & $\mathbf{0 . 9 2 3}$ \\
Z2 & 0.417 & 0.556 & 0.512 & 0.460 & 0.566 & 0.632 & $\mathbf{0 . 8 6 8}$ \\
\hline
\end{tabular}

Dari tabel diatas diketahui bahwa setiap atribut yang mendasari suatu variabel laten selalu memiliki nilai yang lebih tinggi dari pada atribut lain dalam variabel tertentu sehingga dapat dikatakan bahwa data serta model yang dibuat mempunyai discriminant validity yang baik pada nilai cross loading.

Selain itu setelah dilakukan uji validitas diskriminan terhadap masing-masing atribut, maka dapat juga dilakukan terhadap variabel laten yang mendasarinya dengan metode AVE (Average Variance Extracted) dimana jika nilai AVE lebih kecil dari pada akar kuadrat AVE.

Tabel 6. Nilai Average Variance Extracted

\begin{tabular}{|c|c|c|c|c|}
\hline Variabel & AVE & $\begin{array}{c}\text { Akar } \\
\text { Kuadrat } \\
\text { AVE }\end{array}$ & $\begin{array}{l}\text { Nilai } \\
\text { Batas }\end{array}$ & $\begin{array}{c}\text { Validit } \\
\text { as }\end{array}$ \\
\hline
\end{tabular}




\begin{tabular}{|c|c|c|c|c|}
\hline Variabel & AVE & $\begin{array}{c}\text { Akar } \\
\text { Kuadrat } \\
\text { AVE } \\
\end{array}$ & $\begin{array}{l}\text { Nilai } \\
\text { Batas }\end{array}$ & $\begin{array}{l}\text { Validit } \\
\text { as }\end{array}$ \\
\hline Assurance & 0.773 & 0.879 & 0.5 & Valid \\
\hline Empathy & 0.881 & 0.939 & 0.5 & Valid \\
\hline Loyalty & 0.802 & 0.896 & 0.5 & Valid \\
\hline Reliability & 0.589 & 0.767 & 0.5 & Valid \\
\hline $\begin{array}{l}\text { Responsive } \\
\text { ness }\end{array}$ & 0.711 & 0.843 & 0.5 & Valid \\
\hline Satisfaction & 0.836 & 0.914 & 0.5 & Valid \\
\hline Tangible & 0.656 & 0.810 & 0.5 & Valid \\
\hline
\end{tabular}

untuk loyalty berada dibawah 0.6 namun masih dikategorikan dapat dipertimbangkan dalam hal reliabilitas dikarenakan memiliki nilai diatas 0.5. Sehingga atribut serta variabel laten dengan bentuk model yang telah dibuat dapat digunakan dipenelitian lain yang sejenis.

d. Uji Model Struktural

Dari model struktural yang telah dibuat diawal serta adanya perubahan bentuk dikarenakan adanya atribut yang dinyatakan tidak valid dan telah dilakukan uji reliabilitas, maka harus dilakukan lagi uji model struktural dengan melihat hasil bootstraping dengan nilai $\mathrm{R}^{2}$ (koefisien determinasi) terhadap variabel laten endogen.

Tabel 8. Nilai $\mathrm{R}^{2}$ Variabel Laten Endogen

Outer model selain diukur dengan menilai validitas konvergen dan validitas diskriminan juga dapat dilakukan dengan melihat reliabilitas variabel laten yang diukur dengan dua cara, yaitu dengan melihat nilai composite reliability dan cronbach alpha dari blok indikator yang mengukur konstruk. Konstruk dinyatakan reliabel jika nilai composite reliability maupun nilai cronbach alpha lebih besar dari 0.60 .

Tabel 7. Nilai Uji Reliabilitas

\begin{tabular}{ccc}
\hline Variabel & $\begin{array}{c}\text { Cronbach' }^{\prime} \\
\text { s Alpha }\end{array}$ & $\begin{array}{c}\text { Composite } \\
\text { Reliability }\end{array}$ \\
\hline Tangible & 0.731 & 0.849 \\
Reliability & 0.860 & 0.895 \\
Responsiveness & 0.798 & 0.881 \\
Assurance & 0.709 & 0.872 \\
Empathy & 0.768 & 0.895 \\
Satisfaction & 0.621 & 0.757 \\
Loyalty & 0.527 & 0.707 \\
\hline
\end{tabular}

Dari tabel 7 dapat terlihat bahwa hampir semua variabel laten memiliki nilai diatas 0.6 untuk cronbach's alpha dan composite reliability, kecuali

\begin{tabular}{cr}
\hline Variabel Laten Endogen & \multicolumn{1}{c}{$\mathbf{R}^{\mathbf{2}}$} \\
\hline Loyalty & 0.732 \\
Satisfaction & 0.67 \\
\hline
\end{tabular}

Menurut Chin (1998), nilai $\mathrm{R}^{2}$ dianggap lemah, moderat, dan kuat jika menunjukkan secara berurutan sekitar $0.19,0.33$, dan 0.67. Dengan demikian hasil nilai $\mathrm{R}^{2}$ untuk variabel laten tergolong kuat secara model struktural yang telah dibuat.

\section{e. Uji Hipotesis dan Signifikasi}

Uji hipotesis dan signifikansi pada model SEM dengan PLS bertujuan untuk mengetahui pengaruh variabel eksogen terhadap variabel endogen. Pengujian hipotesis dengan metode SEM PLS dilakukan dengan cara melakukan proses bootstrapping dengan bantuan program komputer smartPLS 3.0. Untuk uji hipotesis sendiri menggunakan cara :

- Apabila $\mathrm{t}$ value $<\mathrm{t}$ tabel, maka $\mathrm{H}_{\mathrm{o}}$ diterima.

- Apabila t value > t tabel, maka $\mathrm{H}_{0}$ ditolak.

Nilai t tabel untuk 130 sampel dengan 20 atribut pertanyaan bernilai 1.982 .

Tabel 9. Tabel uji hipotesis

\begin{tabular}{|c|c|c|c|c|c|c|}
\hline No. & Variabel & Koe. Jalur & T Hitung & T Tabel & Kesimpulan & Signifikasi \\
\hline 1 & Tangible -> Satisfaction & 0.160 & 1.663 & 1.983 & H0a diterima & Signifikan \\
\hline 2 & Reliability -> Satisfaction & 0.060 & 0.360 & 1.983 & HOb diterima & Tidak signifikan \\
\hline 3 & $\begin{array}{l}\text { Responsiveness -> } \\
\quad \text { Satisfaction }\end{array}$ & 0.242 & 2.227 & 1.983 & H0c ditolak & Signifikan \\
\hline 4 & Assurance -> Satisfaction & 0.131 & 1.228 & 1.983 & HOd diterima & Signifikan \\
\hline 5 & Empathy -> Satisfaction & 0.367 & 3.476 & 1.983 & H0e ditolak & Signifikan \\
\hline 6 & Tangible -> Loyalty & 0.037 & 0.507 & 1.983 & HOf diterima & Tidak signifikan \\
\hline 7 & Reliability $->$ Loyalty & 0.160 & 1.173 & 1.983 & H0g diterima & Signifikan \\
\hline 8 & Responsiveness -> Loyalty & 0.111 & 1.273 & 1.983 & HOh diterima & Signifikan \\
\hline 9 & Assurance $->$ Loyalty & -0.115 & 1.380 & 1.983 & H0i diterima & Signifikan \\
\hline
\end{tabular}

Rizfanni Chya Putri ${ }^{1}$, Uranio Bimo² / J Statistika Vol. 13, No. 1, (2020) 


\begin{tabular}{ccccccc}
\hline No. & Variabel & Koe. Jalur & T Hitung & T Tabel & Kesimpulan & Signifikasi \\
\hline 10 & Empathy $->$ Loyalty & 0.100 & 1.182 & 1.983 & H0j diterima & Signifikan \\
11 & Satisfaction $->$ Loyalty & 0.635 & 4.846 & 1.983 & H0k ditolak & Signifikan \\
\hline
\end{tabular}

Dari Tabel 9 dapat terlihat bahwa ada beberapa variabel dasar dari kualitas pelayanan yang tidak berpengaruh terhadap kepuasan pengguna jasa serta loyalitas pengguna jasa, seperti variabel tangible, reliability, assurance tidak berpengaruh terhadap satisfaction. Variabel tangible, reliability, responsiveness, assurance, empathy tidak berpengaruh terhadap loyalty. Namun ada juga beberapa variabel dasar dari kualitas pelayanan yang diterima ataupun berpengaruh terhadap variabel laten endogennya, seperti variabel responsiveness berpengaruh terhadap satisfaction, variabel empathy berpengaruh terhadap satisfaction, dan variabel satisfaction berpengaruh terhadap loyalty.

\section{KESIMPULAN DAN SARAN}

Pengujian validitas dan reliabilitas tergolong baik, maka dilanjutkan dengan menghitung customer satisfaction index yang bertujuan mengetahui seberapa besar tingkat kepuasan pengguna jasa terhadap layanan yang diberikan secara aktual oleh pengelola bandar udara, dan menghasilkan nilai yaitu 0.74 atau $74 \%$ kepuasan terhadap pelayanan yang ada.

Dari hasil analisa SEMPLS didapatkan informasi bahwa menurut software smartPLS yang digunakan, hanya 20 indikator yang dapat digunakan dikarenakan indikator Y3, Y4, Z3, Z4 tidak valid dan tidak reliabel dengan bentuk struktural model / path diagram yang digunakan dalam penelitian. Lalu dengan hasil running dari cross loading didapatkan informasi bahwa setiap atribut yang menjadi dasar dari suatu variabel latennya sudah sesuai berdasarkan ketentuan yang ada. Tahap selanjutnya adalah melihat nilai cronbach's alpha dan composite reliabilty yang menginformasikan bahwa semua variabel laten yang digunakan dalam penelitian sudah dikatakan reliabel.

Setelah masing-masing indikator serta variabel latennya telah dilakukan uji secara parsial, maka dilakukan uji model struktural terhadap variabel laten endogennya yaitu loyalty dan satisfaction, dimana menghasilkan informasi bahwa model structural / path diagram yang dilakukan sudah sesuai terhadap variabel laten endogen pada penelitian ini.
Terkait hubungan antara kualitas pelayanan, kepuasan pengguna jasa, serta loyalitas pengguna jasa maka dilakukan uji hipotesis yang menghasilkan informasi seperti variabel tangible, reliability, assurance, tidak berpengaruh terhadap satisfaction. Namun ada juga beberapa variabel yang mempengaruhi yaitu responsivenes, empathy berpengaruh terhadap satisfaction. Variabel tangible, reliability, responsiveness, assurance, empathy tidak berpengaruh terhadap loyalty. Namun variabel satisfaction berpengaruh terhadap loyalty. Dengan demikian secara tidak langsung masih ada keterkaitan hubungan antara kualitas pelayanan, kepuasan pengguna jasa, serta loyalitas pengguna jasa.

Dari penelitian yang telah dilakukan disarankan kepada pengelola pelayanan di bandar udara Juanda Surabaya untuk melakukan peningkatan perihal kualitas pelayanan yang ada, serta memperhatikan beberapa fasilitas/pelayanan yang dirasa pengguna jasa kurang dari harapan. Dengan demikian jika ada peningkatan yang lebih baik dalam hal kualitas maka dimungkinkan juga terjadi kenaikan kepuasan dan loyalitas dari pengguna jasa.

Bagi penelitian yang lain disarankan memakai metode analisa yang berbeda maupun pengukuran dengan faktor yang berbeda selain skytrax sebagai informasi lain terkait pengaruh kualitas pelayanan pada bandar udara terhadap kepuasan pengguna jasa serta loyalitas pengguna jasa.

\section{DAFTAR PUSTAKA}

Cronin, J.J dan Taylor, S.A. 1992. Measuring Service Quality: A Rexxamination and Extension.

Griffin, Jill. 2005. Customer loyalty : Menumbuhkan dan Mempertahankan Kesetiaan Pelanggan. Jakarta : Erlangga.

Kotler, Amstrong. 1999. Prinsip-Prinsip Pemasaran. Jakarta: Erlangga.

Kotler, Amstrong. 2001. Prinsip-prinsip Pemasaran Edisi Keduabelas, Jilid 1. Jakarta: Erlangga

Kotler, Keller. 2009. Manajemen Pemasaran jilid 1 edisi ke 13. Jakarta: Erlangga.

Krajewski, Lee J. dan Ritzman, Larry P. 1990. Operation Management : Strategy and Analysis, $2^{\text {nd }}$ edition. Maccachusetts: AddisonWesley Publishing Company. 
J Statistika Vol. 13, No. 1, (2020), Hal. 22-29

Lovelock, Christopher, Jochen Wirtz, \& Jacky Mussry. 2011. Pemasaran Jasa. edisi 7. Jakarta: Erlangga.
Skytrax. 2013. The World's Best Cabin Crew. Britania Raya. 